\section{Ubiquity of Biological Ice Nucleators in Snowfall}

\author{
Brent C. Christner, ${ }^{1 *}$ Cindy E. Morris, ${ }^{2}$ Christine M. Foreman, ${ }^{3}$ Rongman Cai, ${ }^{1}$ David C. Sands ${ }^{4}$
}

$\Lambda$ erosols play an integral role in climate by directly scattering or absorbing solar radiation, and indirectly these particles serve as condensation and ice nuclei in clouds. Ice formation in tropospheric clouds is required for snow and most rainfall. At temperatures $>-40^{\circ} \mathrm{C}$, ice formation is not spontaneous, and diverse substrates can act as catalysts of ice nucleation (1). Biological ice nucleators (IN) are the most active IN in nature, and some bacterial plant pathogens can catalyze ice formation at temperatures near $-2^{\circ} \mathrm{C}$. Although biological particles are important components of aerosols (2), existing technologies are unable to detect IN active at temperatures $>$ $-10^{\circ} \mathrm{C}(3)$, and the impact of biological IN on atmospheric processes remains ambiguous (4).

We examined the concentration and nature of IN active at temperatures $>-10^{\circ} \mathrm{C}$ in 19 fresh snowfalls collected at mid- and high-latitude locations from October 2005 to June 2006 (5) and found the lowest cumulative concentration of IN at $-9^{\circ} \mathrm{C}$ in Antarctic snowfall (four IN per liter of snow melt) and highest in samples from Montana and France (110 and $120 \mathrm{IN}$ per liter, respectively). DNA-containing cells between 0.3 and $15 \mu \mathrm{m}$ in diameter $\left(1.5 \times 10^{4}\right.$ to
$5.4 \times 10^{6}$ cells per liter) accounted for $<1 \%$ of the total particles in the snow samples $\left(1.1 \times 10^{7}\right.$ to $3.9 \times 10^{9}$ particles per liter), and the concentration of biological IN was independent of the particle and cell concentration (Fig. 1). The data presented in Fig. 1B are for the warmest temperature for which concentrations of IN could be calculated for all samples $\left(-7^{\circ} \mathrm{C}\right)$, thereby facilitating comparison.

The activity of most known biological IN is mediated by proteins or proteinaceous compounds (4). Therefore, we reasoned that IN of biological origin would be inactivated by heat, whereas IN of mineral origin would not. Heat treatment inactivated $69 \%$ to $100 \%$ of the IN active at temperatures $\geq-7^{\circ} \mathrm{C}$ and $\leq-4^{\circ} \mathrm{C}$ (Fig. 1B). In bacteria, ice-nucleation activity depends on an intact cell wall and is conferred by a 120 - to $180-\mathrm{kD}$ protein embedded in the outer membrane (6). Disruption of the cell wall reduces ice-nucleation activity in bacteria (7). Hence, we postulated that lysozyme would decrease the ice-nucleation activity if bacteria were involved and found that 0 to $85 \%$ of the $\mathbb{I N}$ were susceptible to lysozyme (Fig. 1B). Incomplete hydrolysis and resistance to lysozyme could allow some bacterial cells to remain intact in the pres-

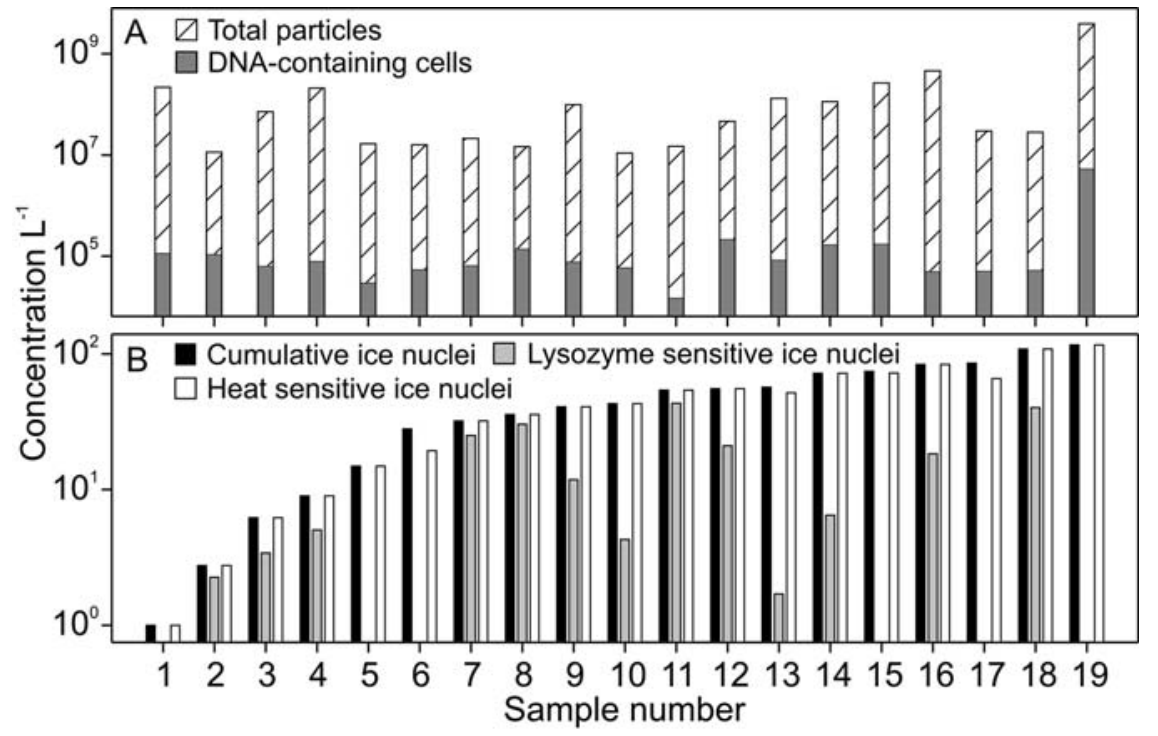

Fig. 1. Particle, cell, and freeze immersion IN concentrations in fresh snowfall collected from Montana, France, the Yukon, and Antarctica. (A) Quantity of particles and DNA-containing cells between 0.3 and $15 \mu \mathrm{m}$ in diameter. (B) The cumulative concentration of IN $(>0.2 \mu \mathrm{m})$ per liter of snow melt that were active at $-7^{\circ} \mathrm{C}$ and sensitive to lysozyme and heat denaturation. From left to right, samples were ranked on the basis of increasing cumulative concentrations of IN. Samples 2, 5 to 8,10 to 12,17 , and 18 were collected in the vicinity of Bozeman, Montana; samples 3, 9, 13 to 16, and 19 from the French Alps and Pyrenees in southern France, and samples 1 and 4 from Ross Island, Antarctica and the Wheaton Glacier, Yukon, respectively. See table S1 for numerical data and detail on sampling dates and site locations.

ence of lysozyme, and, therefore, our results are probably underestimating the concentration of bacterial IN in snowfall.

The samples analyzed were collected during seasons and in locations (e.g., Antarctica) devoid of deciduous plants, making it likely that the biological IN we observed were transported from long distances and maintained their ice-nucleating activity in the atmosphere. Assuming that all biological IN in the snow samples were DNA-containing cells, we estimate that about $0.4 \%$ of the cells in mid-latitude snowfalls were ice-nucleating active at temperatures between $-7^{\circ} \mathrm{C}$ and $-4^{\circ} \mathrm{C}$. Although extrapolating the absolute composition and quantity of biological IN in clouds on the basis of concentrations in precipitation is difficult, our results indicate that these particles are widely dispersed in the atmosphere, and, if present in clouds, they may have an important role in the initiation of ice formation, especially when minimum cloud temperatures are relatively warm.

Biological IN were first described nearly 40 years ago (1); however, there are no estimates for the biological component of $\mathrm{IN}$ in the atmosphere. Our results reveal that biological IN active at warm temperatures are abundant in fresh snow samples and are ubiquitous in precipitation from worldwide locations. Unearthing a role for biological IN in the precipitation cycle has implications for deciphering feedbacks between the biosphere and climate, improving climate forecast models, and understanding atmospheric dissemination strategies of plant pathogens (4) and other microorganisms.

\section{References and Notes}

1. G. Vali, in Biological Ice Nucleation and Its Applications, R. E. Lee Jr., G. J. Warren, L. V. Gusta (American Phytopathological Society Press, St. Paul, MN, 1995), ch. 1.

2. R. Jaenicke, Science 308, 73 (2005).

3. O. Möhler, P. J. DeMott, G. Vali, Z. Levin, Biogeosciences 4, 1059 (2007).

4. C. E. Morris, D. Georgakapolous, D. C. Sands, J. Phys. (Paris) 121, 87 (2004).

5. Materials and methods are available on Science Online.

6. H. Kawahara, J. Biosci. Bioeng. 94, 492 (2002).

7. S. E. Lindow, E. Lahue, A. G. Govindarajan, N. J. Panopoulos, D. Gies, Mol. Plant-Microbe Interact. 2, 262 (1989).

8. We thank F. Johnson, T. Leonard, S. Savage, M. Skidmore, and S. Trautman for collecting snow samples. This research was funded by a Louisiana State University faculty research grant awarded to B.C.C. and NSF grant OPP-0440943 to C.M.F.

\section{Supporting Online Material}

www.sciencemag.org/cgi/content/full/319/5867/1214/DC1 Materials and Methods

Table $\mathrm{S1}$

27 August 2007; accepted 5 December 2007 10.1126/science.1149757

${ }^{1}$ Department of Biological Sciences, Louisiana State University, Baton Rouge, LA 70803, USA. 'L'Institut Nationale de la Recherche Agronomique, Unité de Pathologie Végétale UR407, F-84140 Montfavet, France. ${ }^{3}$ Center for Biofilm Engineering and Department of Land Resources and Environmental Sciences, Montana State University, Bozeman, MT 59717, USA. ${ }^{4}$ Department of Plant Sciences and Plant Pathology, Montana State University, Bozeman, MT 59717, USA.

${ }^{*}$ To whom correspondence should be addressed. E-mail: xner@lsu.edu 